\title{
Komposisi Jenis Tumbuhan dan Analisis Sebaran Langkap (Arenga obtusifolia Mart.) di Taman Nasional Ujung Kulon
}

\section{Composition of Plants and Spread Analysis of Langkap (Arenga obtusifolia Mart.) in Ujung Kulon National Park}

\author{
Indra Febriana $^{\mathrm{a}}$, Cecep Kusmana ${ }^{\mathrm{b}}$, U. Mamat Rahmat ${ }^{\mathrm{c}}$ \\ ${ }^{a}$ Program Studi Pengelolaan Sumberdaya Alam dan Lingkungan, Sekolah Pascasarjana Institut Pertanian Bogor, Kampus IPB \\ Darmaga, Bogor 16680, Indonesia [+6281310318349] \\ ${ }^{\mathrm{b}}$ Departemen Silvikultur, Fakultas Kehutanan, Institut Pertanian Bogor, Kampus IPB Darmaga, Bogor 16680 \\ ${ }^{\mathrm{c}}$ Balai Taman Nasional Ujung Kulon, Direktorat Jenderal Konservasi Sumberdaya Alam dan Ekosistem, Kementerian Lingkungan \\ Hidup dan Kehutanan
}

\section{Article Info:}

Received: 15 - 10 - 2019

Accepted: 18 - 12 - 2019

Keywords:

Arenga obtusifolia, the spread analysis, dominance, Ujung

Kulon National Park

Corresponding Author: Indra Febriana

Program Studi Pengelolaan

Sumberdaya Alam dan

Lingkungan, Sekolah

Pascasarjana Institut Pertanian

Bogor;

Tel. +62-81310318349

Email: ifebriana@gmail.com

\begin{abstract}
Langkap (Arenga obtusifolia) is one of the species of the Arenga clan, which has a wide distribution in Ujung Kulon National Park (UKNP). The Langkap dominance has serious implications for the forest dynamics, including the plant diversity that feeding the Javan Rhino in the park. The aim of study was to determine the pattern of spreading langkap in order to support the management of Javan Rhino habitat. The vegetation analysis method used is a combination method between the line method and the path method. Langkap is the dominant species in UKNP at the sapling growth rate, with a density of 480-624 individuals/ha and INP value of $61.47 \%-78.30 \%$, while the catch density at seedling growth rate is 900-2,200 individuals/ha with INP value of $21.31 \%-49.41 \%$. The standard Morisita coefficient value of langkap in each research block and growth rate is obtained in the range of values (0.32) - 0.51, the spreading pattern shows a clustered spread pattern (Ip>0) and uniform $(I p<0)$. The tendency of langkap domination in the research block can be seen from the ratio of catch density compared to the total density or its relative density at various growth rates. This shows that in the dominant catchment area there is a reduction in the density of plants other than langkap, especially the Javan Rhino feed plants.
\end{abstract}

How to cite (CSE Style $8^{\text {th }}$ Edition):

Febriana I, Kusmana C, Rahmat UM. 2019. Komposisi Jenis Tumbuhan dan Analisis Sebaran Langkap (Arenga obtusifolia Mart.) di Taman Nasional Ujung Kulon. JPSL 10(1): 52-65. http://dx.doi.org/10.29244/jpsl.10.1.52-65.

\section{PENDAHULUAN}

Taman Nasional Ujung Kulon (TNUK) merupakan kawasan pelestarian alam yang memiliki keanekaragaman hayati tinggi, khususnya satwa langka badak jawa (Rhinoceros sondaicus Desmarest, 1822). Pada saat ini badak jawa hanya terdapat di TNUK Provinsi Banten dengan populasi yang relatif kecil. Ukuran populasi yang kecil dan areal penyebaran yang sangat terbatas menyebabkan dinamika ekosistem di kawasan yang menjadi habitat badak jawa akan mempengaruhi perkembangan populasinya. Salah satu aspek penting dari tekanan biologis yang berhubungan dengan hal tersebut adalah suksesi vegetasi, khususnya adanya kecenderungan invasi langkap (Arenga obtusifolia) dan kaitannya dengan penyediaan tumbuhan pakan badak jawa (Putro, 1997). 
Langkap (A. obtusifolia) merupakan salah satu spesies dari marga Arenga, yang sebarannya cukup luas di TNUK. Langkap merupakan salah satu spesies invasif yang bukan merupakan spesies asing, namun menjadi bersifat invasif karena pertumbuhannya tidak terkendali dan mengganggu keberadaan spesies lokal lainnya. Menurut Muntasib dan Putro (1992) diacu dalam Putro dan Siswoyo (1997), langkap memiliki potensi regenerasi yang sangat tinggi karena dapat berbunga sepanjang musim. Kondisi tajuk langkap cukup rapat sehingga menghambat penetrasi cahaya matahari ke lantai hutan. Hal ini berdampak pada terhambatnya regenerasi tumbuhan pakan badak jawa yang umumnya bersifat intoleran, dimana distribusi suatu jenis tumbuhan pada suatu komunitas tertentu dibatasi oleh kondisi lingkungannya (Gunawan et al., 2011).

Sampai dengan saat ini, Balai TNUK telah melakukan pembinaan habitat badak jawa melalui pengendalian spesies invasif langkap. Namun pemetaan langkap di seluruh kawasan TNUK khususnya di Semenanjung Ujung Kulon belum dilakukan secara detil (Rahmat, 2012). Pemetaan ini akan membantu dalam menentukan lokasi-lokasi yang tepat untuk dilakukan pengendalian langkap sebagai dasar pengelolaan habitat badak jawa di TNUK, serta menentukan pola sebaran spasial langkap merupa-kan hal yang perlu dilakukan untuk mengetahui pengaruh sebaran langkap terhadap pengelolaan habitat badak jawa.

Hasil penelitian sebelumnya memberikan indikasi bahwa invasi langkap merupakan penyebab utama terjadinya degradasi habitat badak jawa secara alami dan dalam jangka panjang diduga menyebabkan penurunan populasi satwa tersebut serta menyebabkan penurunan keanekaragaman hayati (biodiversity) di kawasan TNUK (Putro, 1997; Supriatin, 2000; Hariyadi et al., 2012). Berkenaan dengan hal tersebut, maka ketersediaan informasi sebaran langkap sangat diperlukan dalam menjaga kelestarian habitat badak jawa di TNUK. Tujuan penelitian ini adalah mengkaji pola penyebaran langkap dalam rangka mendukung pengelolaan habitat badak jawa.

\section{METODE}

\section{Lokasi Penelitian}

Penelitian dilakukan di Semenanjung Ujung Kulon, Taman Nasional Ujung Kulon (TNUK), yang termasuk dalam kawasan Seksi Pengelolaan Taman Nasional (SPTN) Wilayah II Pulau Handeuleum. Secara administratif lokasi ini termasuk ke dalam wilayah Kecamatan Sumur, Kabupaten Pandeglang, Provinsi Banten, sedangkan secara geografis berada pada posisi geografis $06^{\circ} 38^{\prime} 30^{\prime \prime}-06^{\circ} 52^{\prime} 30^{\prime \prime}$ LS dan $105^{\circ} 12^{\prime} 00^{\prime \prime}-$ 105'37’30" BT. Lokasi penelitian dapat dilihat pada Gambar 1.

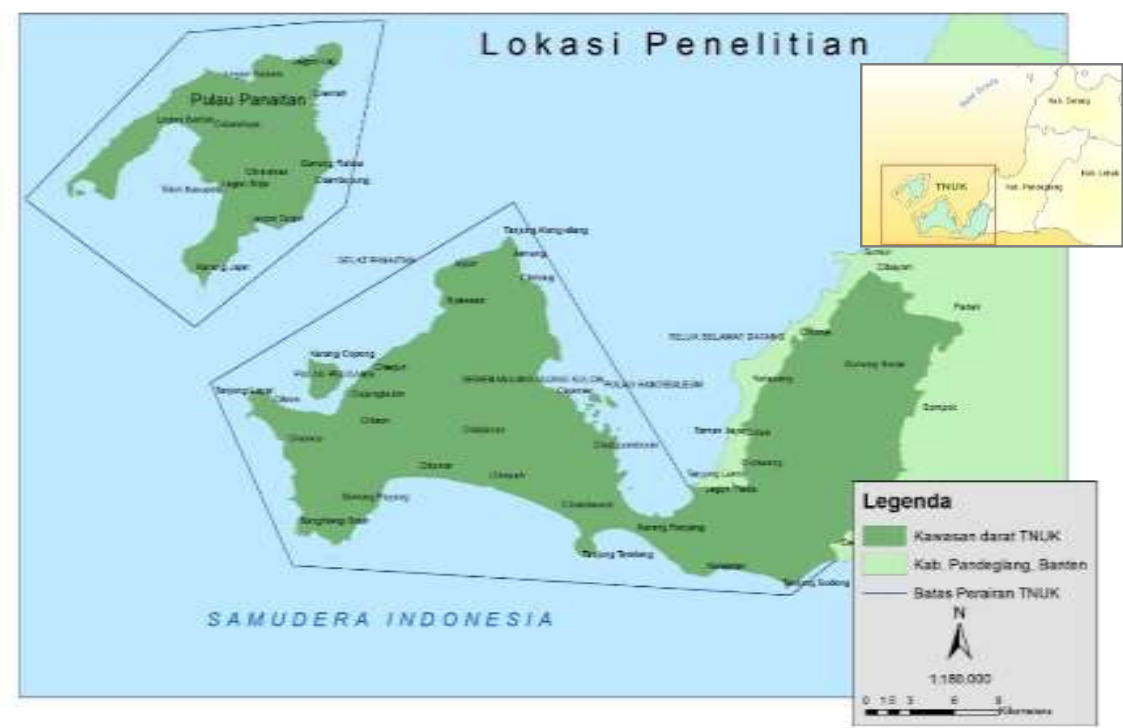

Gambar 1 Lokasi Penelitian. 


\section{Alat dan Bahan}

Peralatan lapangan yang digunakan dalam penelitian ini yaitu: kamera, Global Positioning System (GPS), pita ukur diameter, kompas dan perangkat lunak komputer (SPSS Statistics 19, ArcGIS 9.3, dan ERDAS Imagine 9.1). Bahan yang akan digunakan dalam penelitian ini meliputi: citra LANDSAT 8 path/row 121/65 akuisisi 30 Maret 2016, peta batas kawasan Taman Nasional Ujung Kulon, peta jaringan sungai, peta jaringan jalan dan peta jenis tanah.

\section{Metode Pengumpulan Data}

Dalam studi ini, data struktur vegetasi dan komposisi jenis dikumpulkan melalui metode analisis vegetasi. Analisis vegetasi ini dilakukan dengan cara pengambilan sampling pada lokasi penelitian (Gambar 2). Metode yang digunakan adalah metode kombinasi antara metode garis berpetak dengan metode jalur. Lokasi pengambilan plot contoh pada 4 (empat) lokasi yang telah ditentukan Balai TNUK dalam rangka kegiatan prioritas pengendalian langkap, yaitu terdiri dari 25 petak contoh di Semenanjung Ujung Kulon untuk masingmasing lokasi prioritas (Gambar 2).

Ukuran petak contoh berbentuk persegi dengan ukuran $20 \mathrm{~m}$ x $20 \mathrm{~m}$. Total petak contoh yang dibuat sebanyak 100 petak contoh sehingga luas petak contoh seluas 4 ha. Analisis vegetasi yang dilakukan pada sub petak berupa pengamatan terhadap tumbuhan mulai dari tingkat tumbuhan bawah, semai, pancang, tiang dan pohon, dengan desain pengamatan petak contoh disajikan pada Gambar 3.

Petak A digunakan untuk pengamatan tumbuhan tingkat pohon (diameter $\geq 20 \mathrm{~cm}$ ) dengan luas petak sebesar $20 \mathrm{~m}$ x $20 \mathrm{~m}$, petak B untuk pengamatan tingkat tiang (diameter 10 sampai $<20 \mathrm{~cm}$ ) dengan luas $10 \mathrm{~m}$ $\mathrm{x} 10 \mathrm{~m}$, petak $\mathrm{C}$ untuk pengamatan tingkat pancang (diameter $<10 \mathrm{~cm}$, tinggi $>1,5 \mathrm{~m}$ ) dengan luas $5 \mathrm{~m} \times 5 \mathrm{~m}$ dan petak $\mathrm{D}$ untuk pengamatan ting-kat semai dan tumbuhan bawah (tinggi $<1,5 \mathrm{~m}$; di-ameter $<3 \mathrm{~cm}$ ) dengan luas petak sebesar $2 \mathrm{~m} \times 2 \mathrm{~m}$.

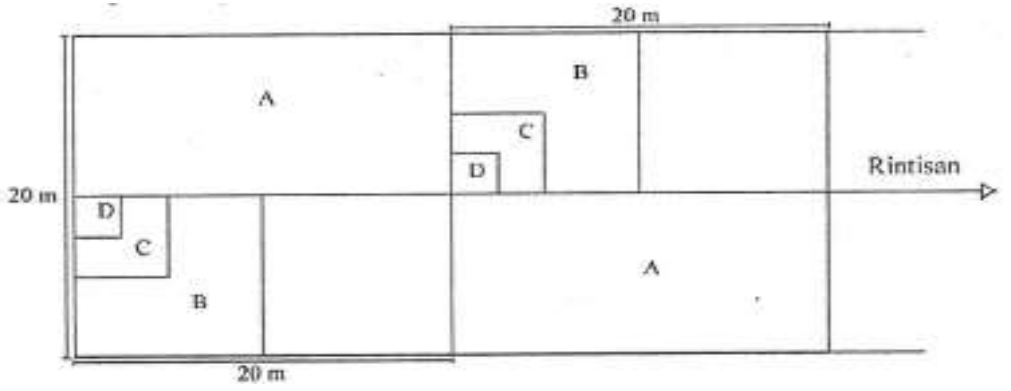

Gambar 3 Desain petak contoh vegetasi.

\section{Variabel yang diamati}

Variabel yang diamati pada masing-masing tingkat pertumbuhan jenis tumbuhan dalam penelitian ini adalah sebagai berikut:

- Tumbuhan tingkat semai: jenis tumbuhan, jumlah individu tiap jenis.

- Tumbuhan tingkat pancang: jenis tumbuhan, jumlah individu tiap jenis, diameter setinggi dada (dbh).

- Tumbuhan tingkat tiang: jenis tumbuhan, jumlah individu tiap jenis, diameter setinggi dada (dbh) dan tinggi vegetasi.

- Tumbuhan tingkat pohon: jenis tumbuhan, jumlah individu tiap jenis, diameter setinggi dada (dbh) dan tinggi vegetasi. 


\section{Metode Analisis Data}

\section{Indeks Nilai Penting (INP)}

Indeks Nilai Penting (INP) digunakan untuk menentukan dominansi suatu jenis terhadap jenis yang lain. Menurut Mueller dan Dumbois (1974), nilai INP merupakan penjumlahan dari kerapatan relatif (KR), dominansi relatif (DR), dan frekuensi relatif (FR) dengan perhitungan sebagai berikut.

$$
\begin{gathered}
\text { Kerapatan }(\mathrm{ind} / \mathrm{ha})=\frac{\text { Jumlah } \text { individu dari suatu jenis }}{\text { Luas contoh }} \\
\text { Kerapatan Relatif }(\%)=\frac{\text { Kerapatan } \text { dari } \text { suatu jenis }}{\text { Kerapatan seluruh jenis }} \times 100 \% \\
\text { Frekuensi }=\frac{\text { Jumlah } \text { plot ditemukannya suatu jenis }}{\text { Jumlah seluruh plot }} \\
\text { Frekuensi Relatif }(\%)=\frac{\text { Frekuensi dari suatu jenis }}{\text { Frekuensi seluruh jenis }} \times 100 \% \\
\text { Dominansi }\left(\mathrm{m}^{2} / \mathrm{ha}\right)=\frac{\text { Jumlah bidang dasar }}{\text { Luas petak contoh }} \\
\text { Dominansi Relatif }(\%)=\frac{\text { Dominansi dari suatu jenis }}{\text { Dominansi seluruh jenis }} \times 100 \%
\end{gathered}
$$

INP $(\%)=$ Kerapatan Relatif + Frekuensi Relatif (untuk tingkat semai, tumbuhan bawah, dan pancang)

INP $(\%)=$ Kerapatan Relatif + Frekuensi Relatif + Dominansi Relatif (untuk tingkat tiang dan pohon)

\section{Indeks Keanekaragaman Jenis}

Keanekaragaman jenis adalah parameter yang sangat berguna untuk membandingkan dua komuni-tas, terutama untuk mempelajari pengaruh gangguan biotik, untuk mengetahui tingkatan suksesi atau kestabilan. Keanekaragaman jenis ditentukan dengan menggunakan rumus Shannon-Wiener (Ludwig dan Reynold, 1988). Bahkan Menurut Magurran (2004) dalam penentuan indeks keanekaragaman jenis rumus Shanon-Wiener paling banyak digunakan karena rumus ini memiliki sensitivitas yang tinggi untuk menggambarkan struktur komunitas dan berfungsi untuk mengetahui perubahan yang terjadi pada jenis-jenis tidak dominan, dengan rumus sebagai berikut.

$$
\mathrm{H}^{\prime}=-\sum\left(\frac{n i}{N} \ln \frac{n i}{N}\right) \text {, dimana: }
$$

$\mathrm{H}^{\prime}=$ Indeks keanekaragaman Shanon-Weiner

ni $=$ INP jenis ke-i

$\mathrm{N}=$ Total INP

Menurut Magurran (2004), nilai indeks keanekaragaman jenis umumnya berada pada kisaran antara 1.0 sampai 3.5. Jika indeks jenis (H') mendekati 3.5 maka menggambarkan tingkat keanekaragaman yang semakin tinggi.

\section{Indeks Kekayaan Jenis}

Perhitungan indeks kekayaan jenis menggunakan rumus Margallef (Ludwig dan Reynold 1988), yaitu :

$$
\mathrm{R} 1=\mathrm{S}-1 / \ln (\mathrm{N}) \text {, dimana: }
$$


R1 = Indeks kekayaan jenis Margallef

$\mathrm{S}=$ Jumlah jenis

$\mathrm{N}$ = Jumlah total individu

Indeks Margallef dapat digunakan untuk mengetahui kekayaan jenis di suatu kawasan. Menurut Magurran (2004) besaran $\mathrm{R} 1<3.5$ menunjukkan kekayaan jenis tergolong rendah, $\mathrm{R} 1=3.5-5.0$ menunjukkan kekayaan jenis tergolong sedang, R1>5.0 kekayaan tergolong tinggi.

\section{Indeks Dominansi}

Indeks dominansi digunakan untuk menentukan dominansi jenis di dalam suatu komunitas sehingga dapat ditentukan posisi dominansi dipusatkan (Misra 1980). Indeks dominansi ditentukan dengan menggunakan rumus sebagai berikut.

$$
\mathrm{C}=\Sigma[\mathrm{ni} / \mathrm{N}], \text { dimana: }
$$

$\mathrm{C}=$ Indeks dominansi

$\mathrm{Ni}=\mathrm{INP}$ tiap jenis

$\mathrm{N}=$ Total INP seluruh jenis

Nilai indeks dominansi mendekati satu (1) apabila dipusatkan pada satu jenis dan sebaliknya apabila nilai indeks dominansi mendekati nol (0) menunjukkan jika pada areal tersebut didominasi secara bersama-sama.

\section{Indeks Penyebaran Jenis}

Analisis pola sebaran langkap menggunakan Indeks Morisita yang terstandar (Standardized Morisita's Index) (Morisita, 1962 dalam Krebs, 1989). Pada umumnya jenis tumbuhan memiliki pola penyebaran yang berbeda. Krebs (1989) menyatakan bahwa untuk melihat pola penyebaran suatu jenis dihitung dengan rumus:

$$
\mathrm{I}_{\mathrm{d}}=n\left[\frac{\sum x^{2}-\sum x}{\left(\sum x\right)^{2}-\sum x}\right] \text {, dimana: }
$$

$\mathrm{I}_{\mathrm{d}}=$ Indeks Penyebaran Morisita

$\mathrm{x}=$ Jumlah individu yang ditemukan pada setiap petak

$\mathrm{n}=$ Jumlah petak pengamatan

Uniform Indeks $=\mathrm{M}_{\mathrm{u}}=\frac{\chi_{0.975}^{2}-n+\sum x_{i}}{\left(\sum x_{i}\right)-1}$

Clumped Indeks $=\mathrm{M}_{\mathrm{c}}=\frac{\chi_{0.025}^{2}-n+\sum x_{i}}{\left(\sum x_{i}\right)-1}$

Keterangan :

$\chi_{0.975}^{2}=$ Nilai dari tabel dengan df (n-1) yang memiliki 97,5\% area ke sebelah kanan kurva

$\chi_{0.025}^{2}=$ Nilai dari tabel dengan df (n-1) yang memiliki 2,5\% area ke sebelah kanan kurva

$\sum x_{i}=$ Jumlah individu dalam kuadrat $\mathrm{i}(\mathrm{i}=1,2, \ldots \mathrm{n})$

$\mathrm{n} \quad=$ Jumlah kuadrat

Berdasarkan hasil indeks $\mathrm{M}_{\mathrm{c}}$ atau $\mathrm{M}_{\mathrm{u}}$ di atas maka Indeks Morisita Standar $\left(\mathrm{I}_{\mathrm{p}}\right)$ dihitung berdasarkan salah satu dari empat persamaan berikut ini:

1. Jika $I_{d} \geq M_{c}>1 \quad: \quad I_{p}=0,5+0,5\left(\frac{I_{d}-M_{c}}{n-M_{c}}\right)$

2. Jika Mc $>\operatorname{Id} \geq 0: \quad I p=0,5\left(\frac{I_{d}-1}{M_{u}-1}\right)$

3. Jika $1>\mathrm{Id}>\mathrm{Mu}: \quad \mathrm{Ip}=-0,5\left(\frac{\mathrm{I}_{\mathrm{d}}-1}{\mathrm{M}_{\mathrm{u}}-1}\right)$ 
4. Jika $1>\mathrm{Mu}>\mathrm{Id}: \quad \mathrm{Ip}=-0,5+0,5\left(\frac{\mathrm{I}_{\mathrm{d}}-\mathrm{M}_{\mathrm{u}}}{\mathrm{M}_{\mathrm{u}}}\right)$

Indeks Morisita yang distandarkan $\left(\mathrm{I}_{\mathrm{p}}\right)$ ini berkisar antara -1 hingga 1 . Jika $\mathrm{I}_{\mathrm{p}}=0$ maka pola penyebaran acak, $\mathrm{I}_{\mathrm{p}}<0$ pola penyebaran seragam dan $\mathrm{I}_{\mathrm{p}}>0$ pola penyebaran mengelompok.

\section{HASIL DAN PEMBAHASAN}

\section{Komposisi Jenis Tumbuhan}

Analisis vegetasi dilakukan pada 4 (empat) blok penelitian, yaitu Blok Citalanca, Blok Cikarang, Blok Cigenter dan Blok Cilintang. Hasil analisis vegetasi diketahui bahwa terdapat 205 jenis tumbuhan yang merupakan jumlah keseluruhan dari tingkat tumbuhan bawah, semai, pancang, tiang dan pohon. Hasil analisis vegetasi pada seluruh blok penelitian berdasarkan tingkat pertumbuhan disajikan pada Tabel 1.

Langkap merupakan salah satu spesies dari suku Arecaceae dan termasuk dalam tumbuhan Monokotil, dengan ciri morfologi batang diantaranya: tegak, bulat dan berbatang lurus, berijuk sedikit dan berbuku-buku, tidak berbanir dan tidak bercabang (Putro dan Siswoyo 1997). Salah satu ciri yang lain dari Suku Arecaceae ini adalah tidak memiliki kambium sejati.

\section{Tingkat Tumbuhan Bawah}

Berdasarkan hasil analisis vegetasi dari seluruh blok penelitian pada tingkat tumbuhan bawah ditemukan sebanyak 29 jenis. Hasil penelitian menunjukkan bahwa Anadendrum microtachyum (Areuy lolo) merupakan jenis dominan yang memiliki nilai INP paling tinggi yaitu sebesar 98.46\%, selanjutnya Daemonorops sp. (Rotan merah) (INP=76.89\%) dan Ficus Montana (Areuy mata) (INP=63.92\%). Daftar tiga jenis tumbuhan bawah dengan nilai INP tertinggi pada seluruh blok penelitian disajikan pada Tabel 2.

Tabel 1 Daftar jumlah jenis tumbuhan pada lokasi penelitian.

\begin{tabular}{lc}
\hline \multicolumn{1}{c}{ Tingkat Pertumbuhan } & Jumlah Jenis \\
\hline Tumbuhan bawah & 29 \\
Semai & 46 \\
Pancang & 41 \\
Tiang & 37 \\
Pohon & 52 \\
\hline
\end{tabular}

Tabel 2 Daftar tiga jenis tumbuhan bawah dengan nilai INP tertinggi pada seluruh blok penelitian.

\begin{tabular}{|c|c|c|c|}
\hline No & Nama Jenis & Nama Latin & Nilai INP (\%) \\
\hline \multicolumn{4}{|c|}{ I. Blok Citalanca } \\
\hline 1 & Rotan merah & Daemonorops sp. & 76.89 \\
\hline 2 & Areuy Lolo & Anadendrum microtachyum & 49.05 \\
\hline 3 & Areuy kutak & Piper bantamense & 19.22 \\
\hline \multicolumn{4}{|c|}{ II. Blok Cikarang } \\
\hline 1 & Areuy kupu & Uvaria sp. & 61.41 \\
\hline 2 & Areuy Lolo & Anadendrum microtachyum & 30.20 \\
\hline 3 & Rotan merah & Daemonorops sp. & 25.77 \\
\hline III. & Blok Cigenter & & \\
\hline 1 & Areuy mata & Ficus montana & 63.92 \\
\hline 2 & Areuy Kolebahe & Trema orientalis & 35.08 \\
\hline 3 & Pepedesan & - & 18.78 \\
\hline IV. & Blok Cilintang & & \\
\hline 1 & Areuy Lolo & Anadendrum microtachyum & 98.46 \\
\hline 2 & Rotan & Daemonorops sp. & 27.12 \\
\hline 3 & Sayar & Caryota mitis & 19.49 \\
\hline
\end{tabular}




\section{Tingkat Semai}

Berdasarkan hasil analisis vegetasi dari seluruh blok penelitian pada tingkat semai ditemukan sebanyak 46 jenis. Hasil penelitian menunjukkan bahwa Diospyros macrophylla (Kicalung) merupakan jenis dominan yang memiliki nilai INP paling tinggi yaitu sebesar 68.98\%, selanjutnya Cynometra ramiflora (Kibatok) (INP=68.76\%) dan Diospyros macrophylla (Kicalung) (INP=51.78\%). Daftar tiga jenis semai dengan nilai INP tertinggi pada seluruh blok penelitian disajikan pada Tabel 3.

Tabel 3 Daftar tiga jenis semai dengan nilai INP tertinggi pada seluruh blok penelitian.

\begin{tabular}{|c|c|c|c|}
\hline No & Nama Jenis & Nama Latin & Nilai INP (\%) \\
\hline \multicolumn{4}{|c|}{ I. Blok Citalanca } \\
\hline 1 & Kicalung & Diospyros macrophylla & 68.98 \\
\hline 2 & Langkap anakan & Arenga obtusifolia & 49.41 \\
\hline 3 & Kibatok & Cynometra ramiflora & 25.61 \\
\hline \multicolumn{4}{|c|}{ II. Blok Cikarang } \\
\hline 1 & Kicalung & Diospyros macrophylla & 51.78 \\
\hline 2 & Langkap anakan & Arenga obtusifolia & 47.32 \\
\hline 3 & Kibatok & Cynometra ramiflora & 17.03 \\
\hline III. & Blok Cigenter & & \\
\hline 1 & Kibatok & Cynometra ramiflora & 68.76 \\
\hline 2 & Kiendog & Cynocroches axillaris & 38.52 \\
\hline 3 & Langkap anakan & Arenga obtusifolia & 29.43 \\
\hline IV. & Blok Cilintang & & \\
\hline 1 & Kililin & - & 42.20 \\
\hline 2 & Kijahe & Croton auypelas & 25.20 \\
\hline 3 & Langkap anakan & Arenga obtusifolia & 21.31 \\
\hline
\end{tabular}

\section{Tingkat Pancang}

Berdasarkan hasil analisis vegetasi dari seluruh blok penelitian pada tingkat pancang ditemukan sebanyak 41 jenis. Hasil penelitian menunjukkan bahwa Arenga obtusifolia (Langkap) merupakan jenis dominan yang memiliki nilai INP paling tinggi yaitu sebesar $78.30 \%$, selanjutnya Arenga obtusifolia (Langkap) (INP=67.63\%) dan Arenga obtusifolia (Langkap) (INP=62.95\%). Daftar tiga jenis pancang dengan nilai INP tertinggi pada seluruh blok penelitian disajikan pada Tabel 4.

\section{Tingkat Tiang}

Berdasarkan hasil analisis vegetasi dari seluruh blok penelitian pada tingkat tiang ditemukan sebanyak 37 jenis. Hasil penelitian menunjukkan bahwa Diospyros javanica (Kigeunteul) merupakan jenis dominan yang memiliki nilai INP paling ting gi yaitu sebesar 96.62\%, selanjutnya Orophea hexandra (Sauhen) (INP=66.19\%) dan Eugenia sp. (Jajambuan) (INP=52.58\%). Daftar tiga jenis tiang dengan nilai INP tertinggi pada seluruh blok penelitian disajikan pada Tabel 5 .

\section{Tingkat Pohon}

Berdasarkan hasil analisis vegetasi dari seluruh blok penelitian pada tingkat pohon ditemukan sebanyak 52 jenis. Hasil penelitian menunjukkan bahwa Eugenia polyantha (Salam) merupakan jenis dominan yang memiliki nilai INP paling tinggi yaitu sebesar 98.35\%, selanjutnya Ficus benyamina (Kiara) (INP=78.27\%) dan Lagerstromeia speciosa (Bungur) (INP=74.01\%). Daftar tiga jenis pohon dengan nilai INP tertinggi pada seluruh blok penelitian disajikan pada Tabel 6 . 
Tabel 4 Daftar tiga jenis pancang dengan nilai INP tertinggi pada seluruh blok penelitian.

\begin{tabular}{|c|c|c|c|}
\hline No & Nama Jenis & Nama Latin & Nilai INP (\%) \\
\hline \multicolumn{4}{|c|}{ I. Blok Citalanca } \\
\hline 1 & Langkap dewasa & Arenga obtusifolia & 67.63 \\
\hline 2 & Kibatok & Cynometra ramiflora & 39.42 \\
\hline 3 & Lampeni & Ardisia humilis & 13.19 \\
\hline \multicolumn{4}{|c|}{ II. Blok Cikarang } \\
\hline 1 & Langkap dewasa & Arenga obtusifolia & 62.95 \\
\hline 2 & Kikeper & - & 41.89 \\
\hline 3 & Kibatok & Cynometra ramiflora & 37.63 \\
\hline \multicolumn{4}{|c|}{ Blok Cigenter } \\
\hline 1 & Langkap dewasa & Arenga obtusifolia & 78.30 \\
\hline 2 & Kibatok & Cynometra ramiflora & 34.42 \\
\hline 3 & Kikacang & Strombosia javanica & 16.93 \\
\hline \multicolumn{4}{|c|}{ IV. $\quad$ Blok Cilintang } \\
\hline 1 & Langkap dewasa & Arenga obtusifolia & 61.47 \\
\hline 2 & Sauhen & Orophea hexandra & 57.03 \\
\hline 3 & Kigeunteul & Diospyros javanica & 21.28 \\
\hline
\end{tabular}

Tabel 5 Daftar tiga jenis tiang dengan nilai INP tertinggi pada seluruh blok penelitian.

\begin{tabular}{|c|c|c|c|}
\hline No & Nama Jenis & Nama Latin & Nilai INP (\%) \\
\hline \multicolumn{4}{|c|}{ I. Blok Citalanca } \\
\hline 1 & Kigeunteul & Diospyros javanica & 96.62 \\
\hline 2 & Jajambuan & Eugenia sp & 52.58 \\
\hline 3 & Huru batu & Litsea vulva & 26.29 \\
\hline \multicolumn{4}{|c|}{ II. Blok Cikarang } \\
\hline 1 & Kicalung & Diospyros macrophylla & 51.91 \\
\hline 2 & Kikeper & - & 47.01 \\
\hline 3 & Kigeunteul & Diospyros javanica & 35.88 \\
\hline \multicolumn{4}{|c|}{ Blok Cigenter } \\
\hline 1 & Kicalung & Diospyros macrophylla & 43.74 \\
\hline 2 & Ipis kulit & Decaspermum fruticosum & 42.19 \\
\hline 3 & Sauhen & Orophea hexandra & 23.94 \\
\hline \multicolumn{4}{|c|}{ Blok Cilintang } \\
\hline 1 & Sauhen & Orophea hexandra & 66.19 \\
\hline 2 & Kililin & Phaleria octendre & 34.68 \\
\hline 3 & Kijahe & Croton auypelas & 31.51 \\
\hline
\end{tabular}


Tabel 6 Daftar tiga jenis pohon dengan nilai INP tertinggi pada seluruh blok penelitian.

\begin{tabular}{cllc}
\hline \multicolumn{1}{c}{ No } & \multicolumn{1}{c}{ Nama Jenis } & Nilai INP (\%) \\
\hline I. & Blok Citalanca & \multicolumn{1}{c}{ Lagerstromeia speciosa } & 74.01 \\
1 & Bungur & Ficus benyamina & 65.09 \\
2 & Kiara & Diospyros macrophylla & 27.71 \\
3 & Kicalung & Ficus benyamina & 78.27 \\
\hline II. & Blok & Cikarang & 43.57 \\
1 & Kiara & Lagerstromeia speciosa & 25.31 \\
2 & Bungur & - & \\
3 & Kigelam & Eugenia polyantha & 98.35 \\
\hline III. & Blok Cigenter & Ficus benyamina & 49.12 \\
1 & Salam & Lagerstromeia speciosa & 29.75 \\
2 & Kiara & & \\
3 & Bungur & Diospyros javanica & 29.49 \\
\hline IV. & Blok Cilintang & Dracontomelon dao & 25.32 \\
1 & Kigeunteul & - & 22.44 \\
2 & Dahu & & \\
3
\end{tabular}

Kerapatan individu pada tingkat tumbuhan bawah dan semai lebih banyak didominasi oleh jenis tumbuhan yang merupakan sumber pakan badak jawa, diantaranya kicalung, ipis kulit, dan sulangkar.

Hasil penelitian menunjukkan bahwa langkap (Arenga obtusifolia) merupakan jenis yang memiliki kerapatan paling tinggi kedua dalam populasi tingkat pancang yaitu sebesar 624 individu/ha, dengan penyebaran individu yang merata. Tabel 7. menggambarkan lima jenis tumbuhan masing-masing tingkat pertumbuhan dengan kerapatan tertinggi pada seluruh blok penelitian. Berdasarkan Tabel 7. diketahui bahwa Areuy mata (Ficus Montana) merupakan jenis yang memiliki kerapatan tertinggi pada tingkat tumbuhan bawah yaitu sebesar 14.800 individu/ha. Adapun jenis tumbuhan pada tingkat semai, pancang, tiang dan pohon yang memiliki kerapatan tertinggi secara berurutan yaitu Kililin (Phaleria octendre) sebesar 12.400 individu/ha, Sauhen (Orophea hexandra) sebesar 752 individu/ha, Kigeunteul (Diospyros javanica) sebesar 32 individu/ha dan Bungur (Lagerstromeia speciosa) sebesar 28 individu/ha.

\section{Keanekaragaman Jenis Tumbuhan}

\section{Indeks Keanekaragaman Jenis (H')}

Keanekaragaman jenis tumbuhan di blok penelitian berdasarkan Indeks Keanekaragaman Jenis ShannonWeiner termasuk dalam kategori sedang $\left(1<\mathrm{H}^{\prime}<3,32\right)$ dengan kisaran nilai indeks sebesar 2.00-2.60 (Tabel 8.). Keanekaragaman jenis yang tertinggi pada tingkat pohon (2.60), sedangkan keanekaragaman jenis terendah pada tingkat tumbuhan bawah (2.00). Secara umum blok penelitian Cilintang mempunyai keanekaragaman jenis paling tinggi dibandingkan dengan blok penelitian yang lain, dengan rata-rata nilai indeks keanekaragaman setiap tingkat pertumbuhan sebesar 2.37.

Pada tingkat semai, tiang dan pohon blok penelitian Cilintang mempunyai keanekaragaman jenis tumbuhan tertinggi. Blok penelitian Cilintang umumnya mempunyai kondisi hutan yang cukup baik dengan naungan dan kerapatan pohon yang tinggi dibandingkan dengan blok penelitian yang lain, sehingga banyak jenis yang dapat tumbuh di lokasi tersebut. Tingkat keanekaragaman jenis dapat diketahui berdasarkan indeks dominansi, indeks keanekaragaman, indeks kekayaan, dan indeks kemerataan jenis (Istomo dan Sari 2018). 
Tabel 7 Lima jenis tumbuhan pada berbagai tingkat pertumbuhan dengan kerapatan tertinggi di seluruh blok penelitian.

\begin{tabular}{|c|c|c|c|}
\hline Nama Jenis & Nama Latin & Famili & Kerapatan (Ind./ha) \\
\hline \multicolumn{4}{|c|}{ Tumbuhan Bawah } \\
\hline Areuy mata & Ficus montana & Moraceae & 14.800 \\
\hline Areuy Lolo & Anadendrum microtachyum & Araceae & 9.900 \\
\hline Areuy kupu-kupu & Uvaria sp. & Annonaceae & 8.500 \\
\hline Areuy Kolebahe & Trema orientalis & Cannabaceae & 5.400 \\
\hline Rotan merah & Daemonorops sp. & Arecaceae & 5.200 \\
\hline \multicolumn{4}{|c|}{ Semai } \\
\hline Kililin & Phaleria octendre & Thymelaeaceae & 12.400 \\
\hline Kijahe & Croton auypelas & Euphorbiaceae & 8.500 \\
\hline Kisariawan & Symplocos conchinchinensis & Symplocaceae & 6.100 \\
\hline Leungsir & Pometia pinnata & Sapindaceae & 5.100 \\
\hline Kicalung & Diospyros macrophylla & Ebenaceae & 4.500 \\
\hline \multicolumn{4}{|c|}{ Pancang } \\
\hline Sauhen & Orophea hexandra & Annonaceae & 752 \\
\hline Langkap & Arenga obtusifolia & Arecaceae & 624 \\
\hline Kibatok & Cynometra ramiflora & Leguminosae & 608 \\
\hline Kikeper & Engelhardia spicata & Junglandaceae & 528 \\
\hline Kigeunteul & Diospyros javanica & Ebenaceae & 208 \\
\hline \multicolumn{4}{|c|}{ Tiang } \\
\hline Kigeunteul & Diospyros javanica & Ebenaceae & 32 \\
\hline Ipis kulit & Decaspermum fruticosum & Myrtaceae & 28 \\
\hline Kicalung & Diospyros macrophylla & Ebenaceae & 28 \\
\hline Sauhen & Orophea hexandra & Annonaceae & 28 \\
\hline Kikacang & Strombosia javanica & Olacaceae & 16 \\
\hline \multicolumn{4}{|c|}{ Pohon } \\
\hline Bungur & Lagerstromeia speciosa & Lythraceae & 28 \\
\hline Salam & Eugenia polyantha & Myrtaceae & 14 \\
\hline Kicalung & Diospyros macrophylla & Ebenaceae & 12 \\
\hline Kiara & Ficus benjamina & Moraceae & 10 \\
\hline Kikacang & Strombosia javanica & Palmae & 8 \\
\hline
\end{tabular}

Tabel 8 Nilai indeks keanekaragaman jenis pada berbagai tingkat pertumbuhan.

\begin{tabular}{lccccc}
\hline \multirow{2}{*}{ Tingkat Pertumbuhan } & \multicolumn{4}{c}{ Blok Penelitian } & \multirow{2}{*}{ Rata-rata } \\
\cline { 2 - 5 } & Citalanca & Cikarang & Cigenter & Cilintang & \\
\hline Tumbuhan bawah & 1.91 & 2.09 & 2.21 & 1.77 & 2.00 \\
Semai & 1.96 & 1.92 & 2.00 & 2.62 & 2.13 \\
Pancang & 2.23 & 2.04 & 2.19 & 2.00 & 2.12 \\
Tiang & 1.92 & 2.22 & 2.03 & 2.40 & 2.14 \\
Pohon & 2.46 & 2.53 & 2.34 & 3.08 & 2.60 \\
\hline
\end{tabular}

\section{Indeks Kekayaan Jenis (R1)}

Hasil analisis kekayaan jenis di blok penelitian berdasarkan Indeks Kekayaan Jenis Margallef menghasilkan kisaran nilai indeks antara 2.30-5.04 (Tabel 9) dengan rata-rata sebesar 3.44, hal ini mengindikasikan bahwa kekayaan jenis tergolong rendah.

Pada tingkat pertumbuhan pohon blok penelitian Cilintang mempunyai kekayaan jenis tertinggi (6.53), hal tersebut mengindikasikan bahwa terdapat jenis pohon dan jumlah individu yang cukup banyak. 
Tabel 9 Nilai indeks kekayaan jenis pada berbagai tingkat pertumbuhan.

\begin{tabular}{lccccc}
\hline \multirow{2}{*}{ Tingkat Pertumbuhan } & \multicolumn{4}{c}{ Blok Penelitian } & \multirow{2}{*}{ Rata-rata } \\
\cline { 2 - 5 } & Citalanca & Cikarang & Cigenter & Cilintang & \\
\hline Tumbuhan bawah & 2.46 & 1.95 & 2.42 & 2.38 & 2.30 \\
\hline Semai & 2.78 & 3.13 & 2.78 & 3.55 & 3.06 \\
\hline Pancang & 3.16 & 2.90 & 4.12 & 2.87 & 3.26 \\
\hline Tiang & 2.20 & 3.06 & 5.17 & 3.64 & 3.52 \\
\hline Pohon & 4.09 & 4.91 & 4.64 & 6.53 & 5.04 \\
\hline
\end{tabular}

\section{Indeks Dominansi $(C)$}

Hasil analisis dominansi jenis berdasarkan Indeks Dominansi menunjukkan bahwa nilai indeks dominansi tidak ada yang mendekati satu, yaitu kisaran nilai indeks antara 0.12-0.21 (Tabel 10.) sehingga dapat dikatakan bahwa indeks dominansi jenis di blok penelitian tergolong rendah dan tidak ada jenis yang mendominasi kawasan. Menurut Magurran (2004), nilai C akan bernilai 1 atau mendekati 1 apabilai dominansi dipusatkan pada satu atau sedikit jenis. Sebaliknya, jika beberapa jenis mendominasi secara bersama-sama maka nilai $\mathrm{C}$ akan bernilai rendah atau bahkan mendekati 0 .

Tabel 10 Nilai indeks dominansi pada berbagai tingkat pertumbuhan.

\begin{tabular}{lccccc}
\hline \multirow{2}{*}{ Tingkat Pertumbuhan } & \multicolumn{4}{c}{ Blok Penelitian } & \multirow{2}{*}{ Rata-rata } \\
\cline { 2 - 5 } & Citalanca & Cikarang & Cigenter & Cilintang & \\
\hline Tumbuhan bawah & 0.23 & 0.16 & 0.16 & 0.28 & 0.21 \\
\hline Semai & 0.21 & 0.15 & 0.19 & 0.10 & 0.16 \\
\hline Pancang & 0.17 & 0.19 & 0.20 & 0.20 & 0.19 \\
\hline Tiang & 0.18 & 0.12 & 0.08 & 0.11 & 0.12 \\
\hline Pohon & 0.13 & 0.12 & 0.16 & 0.05 & 0.12 \\
\hline
\end{tabular}

\section{Populasi Langkap}

Langkap merupakan jenis yang dominan di TNUK pada tingkat pertumbuhan pancang (langkap dewasa), dengan kerapatan 480-624 individu/ha dan nilai INP sebesar 61.47\%-78.30\%, sedangkan kerapatan langkap pada tingkat pertumbuhan semai (langkap anakan) sebesar 900-2.200 individu/ha dengan nilai INP 21.31\%49.41\%. Struktur populasi langkap di TNUK menggambarkan bahwa jumlah individu permudaan lebih banyak dari pada tingkat pertumbuhan diatasnya, hal ini terlihat dari jumlah kerapatan langkap pada tingkat pertumbuhan semai lebih banyak dibandingkan kerapatan langkap pada tingkat pertumbuhan pancang.

Hasil analisis vegetasi di 4 (empat) blok penelitian menunjukkan bahwa langkap merupakan jenis yang dominan dengan nilai INP tertinggi dibandingkan jenis lainnya sebesar 78,30\% pada tingkat pertumbuhan pancang di blok penelitian Cigenter. Hal ini menunjukkan adanya kemungkinan pertumbuhan langkap untuk menginvasi kawasan di sekitarnya lebih luas karena jumlah permudaan langkap yang banyak. Nilai INP langkap di setiap blok penelitian disajikan pada Tabel 11.

Tabel 11 Nilai INP langkap di setiap blok penelitian.

\begin{tabular}{cc}
\hline Blok Penelitian & Nilai INP \\
\hline Citalanca & 67,63 \\
\hline Cikarang & 62,95 \\
\hline Cigenter & 78,30 \\
\hline Cilintang & 61,47 \\
\hline
\end{tabular}


Secara umum seluruh blok penelitian memiliki kerapatan langkap yang relatif tinggi pada tingkat pertumbuhan semai dan pancang, tetapi pada tingkat pertumbuhan pohon dan tiang memiliki kerapatan yang rendah. Blok penelitian Citalanca memiliki kerapatan langkap pada tingkat pertumbuhan pancang yang tinggi dibandingkan blok penelitian yang lain, yaitu 624 individu/ha, sedangkan pada tingkat per-tumbuhan semai kerapatan langkap tertinggi pada blok penelitian Citalanca dan Cikarang yaitu masing-masing 2.200 individu/ha. (Gambar 2). Tingginya kerapatan langkap pada blok penelitian Citalanca dikarenakan pada blok penelitian tersebut mempunyai penutupan tajuk yang rapat sehingga sangat mendukung pertumbuhan langkap. Kecenderungan dominasi langkap di blok penelitian dapat diketahui dari rasio kerapatan langkap dibandingkan dengan kerapatan total atau kerapatan relatifnya pada berbagai tingkat pertumbuhan. Diketahui bahwa semakin besar kerapatan langkap pada tingkat pertumbuhan pancang, semakin besar pula kerapatan langkap pada tingkat pertumbuhan semai. Kondisi tersebut menunjukkan tingginya stabilitas regenerasi langkap di blok penelitian. Hal ini menunjukkan bahwa pada kawasan langkap yang dominan maka terjadi pengurangan kerapatan tumbuhan selain langkap, sehingga akan menyebabkan kecenderungan dominansi langkap semakin kuat.

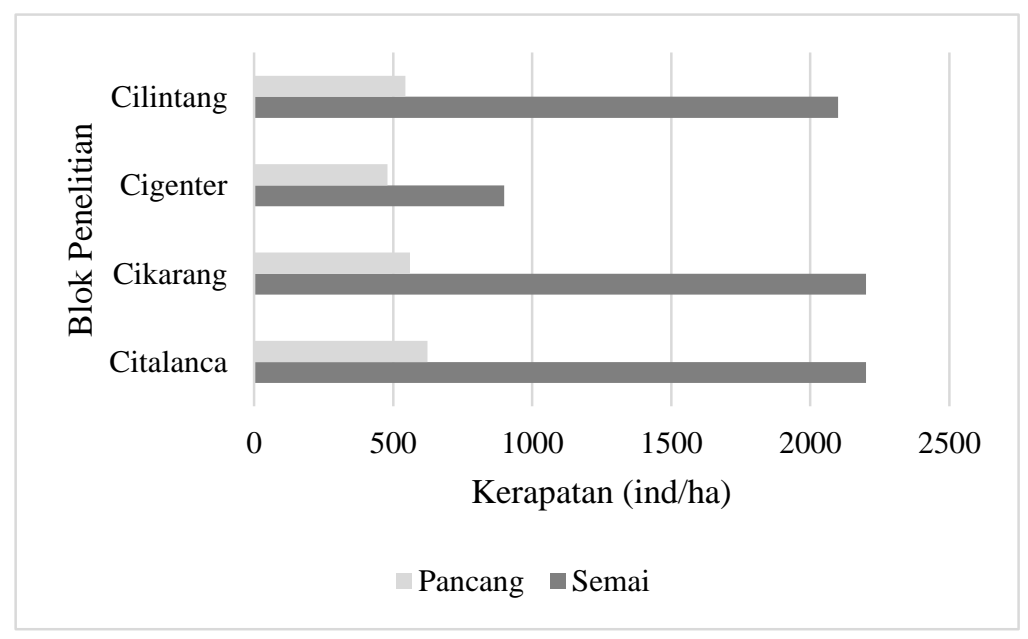

Gambar 2 Kerapatan dan struktur populasi langkap.

\section{Pola Penyebaran Langkap}

Krebs (1989) dalam Usmadi (2015) menyatakan bahwa Indeks Morisita merupakan metode yang digunakan untuk mengetahui pola penyebaran jenis dalam ekosistem. Hasil analisis dan perhitungan terhadap populasi langkap di setiap blok penelitian diperoleh nilai indeks penyebaran Morisita (Id) pada setiap tingkat pertumbuhan bervariasi dengan nilai 1.01-1.37 (Tabel 12.). Selanjutnya nilai indeks penyebaran Morisita tersebut dilakukan pengujian untuk dicari dua titik kritisnya yaitu indeks Mu (Uniform Indeks) dan Mc (Clumped Indeks) melalui uji chi-square, selain itu juga perlu dilakukan standarisasi sehingga diperoleh nilai koefisien Morisita standar (I $p$ ).

Nilai koefisien Morisita standar pada setiap blok penelitian dan tingkat pertumbuhan diperoleh kisaran nilai $0.32-0.51$, maka pola penyebaran langkap menunjukan pola penyebaran mengelompok (Ip $>0$ ). Nilai indeks Morisita terstandar dan pola penyebaran langkap pada setiap tingkat pertumbuhan dan blok penelitian disajikan pada Tabel 12 .

Hasil pengamatan di lapangan diketahui bahwa sebaran langkap tiap blok penelitian dijumpai mengelompok dengan jumlah individu langkap sedikit sampai sangat banyak di setiap plot contoh (20 m x $20 \mathrm{~m}$ ), kisaran 5-150 individu per plot contoh. Pola penyebaran langkap yang mengelompok diindikasikan adanya pengaruh faktor perkembangbiakan dan faktor lingkungan. 
Tabel 12 Nilai indeks Morisita Langkap.

\begin{tabular}{lccccc}
\hline \multicolumn{1}{c}{ Blok Penelitian } & $\mathrm{I}_{d}$ & $\mathrm{M}_{\mathrm{u}}$ & $\mathrm{M}_{\mathrm{c}}$ & $\mathrm{I}_{p}$ & Pola Penyebaran \\
\hline Citalanca & & & & & \\
Langkap dewasa & 1.06 & 0.98 & 1.02 & 0.50 & Mengelompok \\
Langkap anakan & 1.04 & 0.99 & 1.01 & 0.50 & Mengelompok \\
\hline Cikarang & & & & & \\
Langkap dewasa & 1.04 & 0.98 & 1.03 & 0.50 & Mengelompok \\
Langkap anakan & 1.10 & 0.99 & 1.00 & 0.50 & Mengelompok \\
\hline Cigenter & & & & & \\
Langkap dewasa & 1.18 & 0.98 & 1.03 & 0.50 & Mengelompok \\
Langkap anakan & 1.37 & 0.99 & 1.02 & 0.51 & Mengelompok \\
\hline Cilintang & & & & & \\
Langkap dewasa & 1.01 & 0.98 & 1.03 & 0.32 & Mengelompok \\
Langkap anakan & 1.08 & 0.99 & 1.01 & 0.50 & Mengelompok \\
\hline
\end{tabular}

Langkap dapat berkembangbiak secara vegetatif melalui tunas akar (Haryanto, 1997). Tunas akar tersebut akan tumbuh menjadi individu-individu baru yang masih dekat dengan induknya, sehingga membentuk koloni langkap. Penyebaran biji langkap di habitat alaminya dibantu oleh musang (Paradoxurus hermaphroditus), badak jawa (Rhinoceros sondaicus) dan banteng (Bos javanicus) (Haryanto, 1997). Biji tersebut akan keluar dari tubuh satwa tersebut melalui feses dan akan berkecambah di area yang tidak jauh dari habitat langkap tersebut. Sedangkan berdasarkan faktor lingkungan, hasil pengamatan di lapangan dapat diketahui bahwa langkap ditemukan pada lokasi yang mempunyai naungan yang tinggi dan rapat, namun langkap tidak ditemukan pada lokasi yang berdekatan dekat pantai atau lokasi dengan penutupan tajuk yang sangat terbuka.

Kecenderungan dominasi langkap di blok penelitian diketahui dari rasio kerapatan langkap dibandingkan dengan kerapatan total atau kerapatan relatifnya pada berbagai tingkat pertumbuhan. Diketahui bahwa semakin besar kerapatan langkap pada tingkat pertumbuhan pancang, semakin besar pula kerapatan langkap pada tingkat pertumbuhan semai. Kondisi tersebut menunjukkan tingginya stabilitas regenerasi langkap di blok penelitian.

\section{SIMPULAN}

Pola penyebaran langkap pada tingkat pertumbuhan semai (langkap anakan) dan pancang (langkap dewasa) memiliki pola penyebaran mengelompok ( $\mathrm{I} p>0$ ), dengan kisaran nilai koefisien Morisita standar (I $p$ ) 0.32-0.51. Pola penyebaran langkap yang mengelompok diindikasikan adanya pengaruh faktor perkembangbiakan dan faktor lingkungan.

\section{DAFTAR PUSTAKA}

Gunawan W, Basuni S, Indrawan A, Prasetyo LB, Soedjito H. 2011. Analisis komposisi dan struktur vegetasi terhadap upaya restorasi Kawasan Hutan Taman Nasional Gunung Gede Pangrango. Jurnal Pengelolaan Sumberdaya Alam dan Lingkungan. (1) 2 : 93-105.

Hariyadi ARS. 2012. Model Pengelolaan Populasi Badak Jawa (Rhinoceros sondaicus) Berdasarkan Analisis Nutrisi dan Tingkat Cekaman sebagai Parameter Kesehatan. [Disertasi]. Bogor (ID):Institut Pertanian Bogor.

Istomo dan Sari PN. 2018. Penyebaran dan karakteristik habitat jenis rasamala (Altingia excelsa Noronha) di Taman Nasional Gunung Halimun Salak. Jurnal Pengelolaan Sumberdaya Alam dan Lingkungan. 9(3): 608-625. http://dx.doi.org/10.29244/jpsl.9.3.608-625.

Krebs JC. 1989. Ecological Methodology. New York (USA): Harper Collins Publisher, Inc.

Ludwig JA, Reynold JF. 1988. Statistical Ecology, A Primer on Methods and Computing. New York (USA): John Willey and Sons.

Magurran. 2004. Measuring Biological Diversity. Oxford (UK): Blackwell Science Ltd. 
Misra, K.C. 1980. Manual of Plant Ecology. 2nd ed. New Delhi: Oxford \& IBH Publishing Co.

Mueller-Dumbois, D. and D. H. Ellenberg. 1974. Aims and Methods of Vegetation Ecology. New York (USA): John Wiley \& Son.

Putro HR. 1997. Invasi langkap dan dampaknya terhadap keanekaragaman hayati di Taman Nasional Ujung Kulon, Jawa Barat. Media Konservasi Edisi Khusus. 95-100.

Putro HR. 1997. Heterogenitas habitat Badak Jawa (Rhinoceros sondaicus, Demarest 1822) di Taman Nasional Ujung Kulon, Jawa Barat. Media Konservasi Edisi Khusus. 17-40.

Putro HR, Siswoyo. 1997. Sifat-sifat Morfologis dan Anatomis Langkap (Arenga obusifolia Blumme ex Mart). Media Konservasi Edisi Khusus. 105-109.

Rahmat UM. 2012. Sebaran Spasial dan Model Kesesuaian Habitat Badak Jawa (Rhinoceros sondaicus, Demarest 1822) di Taman Nasional Ujung Kulon. [disertasi]. Bogor (ID): Institut Pertanian Bogor.

Soerianegara I, Indrawan A. 2015. Ekologi Hutan Indonesia. Bogor (ID): Laboratorium Ekologi Hutan. Fakultas Kehutanan. Institut Pertanian Bogor.

Supriatin. 2000. Studi kemungkinan adanya pengaruh alleopati langkap (Arenga obtusifolia Blume ex Mart.) terhadap pertumbuhan semai tumbuhan pakan badak jawa di Taman Nasional Ujung Kulon. [skripsi]. Bogor (ID): Institut Pertanian Bogor.

Usmadi, D. 2015. Autekologi dan Kesesuaian Habitat Langkap (Arenga obtusifolia Mart.) di Cagar Alam Leuweung Sancang, Jawa Barat. [tesis]. Bogor (ID): Institut Pertanian Bogor. 